\title{
The Supporting-Cell Antigen: A Receptor-Like Protein Tyrosine Phosphatase Expressed in the Sensory Epithelia of the Avian Inner Ear
}

\author{
Robert P. Kruger, ${ }^{1}$ Richard J. Goodyear, ${ }^{1}$ P. Kevin Legan,, ${ }^{1}$ Mark E. Warchol, ${ }^{2}$ Yehoash Raphael, ${ }^{3}$ \\ Douglas A. Cotanche, ${ }^{4}$ and Guy P. Richardson ${ }^{1}$ \\ 1School of Biological Sciences, The University of Sussex, Falmer, Brighton, BN1 9QG, United Kingdom, ${ }^{2}$ Central Institute \\ for the Deaf, St. Louis, Missouri 63110, 3Kresge Hearing Research Institute, Ann Arbor, Michigan 48109-0648, and \\ 4 Department of Otolaryngology and Communication Disorders, The Children's Hospital, Boston Massachusetts 02115
}

\begin{abstract}
After noise- or drug-induced hair-cell loss, the sensory epithelia of the avian inner ear can regenerate new hair cells. Few molecular markers are available for the supporting-cell precursors of the hair cells that regenerate, and little is known about the signaling mechanisms underlying this regenerative response. Hybridoma methodology was used to obtain a monoclonal antibody (mAb) that stains the apical surface of supporting cells in the sensory epithelia of the inner ear. The mAb recognizes the supporting-cell antigen (SCA), a protein that is also found on the apical surfaces of retinal Müller cells, renal tubule cells, and intestinal brush border cells. Expression screening and molecular cloning reveal that the SCA is a novel receptor-like protein tyrosine phosphatase (RPTP), sharing similarity with human density-enhanced phosphatase, an RPTP
\end{abstract}

The sensory epithelia of the inner ear contain mechanosensitive hair cells that are surrounded and isolated from each other by nonsensory supporting cells. In the avian basilar papilla, these two cell types derive from a common embryonic lineage (Fekete et al., 1998), and it is thought that the decision to become either a hair cell or a supporting cell is made after the progenitors have left the cell cycle. In the mature bird, the hair cells are postmitotic, and the supporting cells are essentially mitotically quiescent (Oesterle and Rubel, 1993). After noise- or drug-induced haircell loss, some of the supporting cells reenter the cell cycle and undergo one or more rounds of cell division, with the progeny then differentiating as either new hair cells or new supporting cells (Corwin and Cotanche, 1988; Ryals and Rubel, 1988; Raphael, 1992, 1993; Stone and Cotanche, 1994). Supporting cells in the basilar papilla may also be able to convert directly into hair cells without reentering the cell cycle after hair-cell loss (Adler and Raphael, 1996; Roberson et al., 1996), suggesting there could be two different mechanisms whereby hair cells can be regener-

\footnotetext{
Received Dec. 23, 1998; revised March 29, 1999; accepted April 7, 1999.

This work was supported by grants from the Wellcome Trust, the Medical Research Council, Defeating Deafness, the National Organization for Hearing Research (D.A.C.), and National Institutes of Health/National Institute on Deafness and Other Communication Disorders Grants DC02291 (M.E.W.), DC03568 (Y.R.), and DC01689 (D.A.C.). The authors thank Cecylia Malenczak, Laura Perry, and Elizabeth Messana for excellent technical assistance, and Jonathan Gale for his helpful criticism of this manuscript.

The nucleotide sequence reported in this paper has been submitted to the EMBL Nucleotide Sequence Database with accession number AJ238216.

Correspondence should be addressed to Dr. Guy P. Richardson, School of Biological Sciences, The University of Sussex, Falmer, Brighton, BN1 9QG, UK. Copyright (C) 1999 Society for Neuroscience $0270-6474 / 99 / 194815-13 \$ 05.00 / 0$
}

thought to have a role in the density-dependent arrest of cell growth. In response to hair-cell damage induced by noise in vivo or hair-cell loss caused by ototoxic drug treatment in vitro, some supporting cells show a dramatic decrease in SCA expression levels on their apical surface. This decrease occurs before supporting cells are known to first enter S-phase after trauma, indicating that it may be a primary rather than a secondary response to injury. These results indicate that the SCA is a signaling molecule that may influence the potential of nonsensory supporting cells to either proliferate or differentiate into hair cells.

Key words: receptor protein tyrosine phosphatase; inner ear; hair cell; supporting cell; development; regeneration ated in the avian inner ear. However, in both cases, the nonsensory supporting cells are considered to be the progenitors for the new hair cells.

Hair-cell damage or loss may be the primary stimulus for the onset of hair-cell regeneration, but little is known about the molecular mechanisms and signaling pathways that underlie this response. Several different growth factors have been shown to stimulate supporting-cell proliferation in cultures of both the avian and mammalian vestibular epithelia (Yamashita and Oesterle, 1995: Oesterle et al., 1997; Zheng et al., 1997), and immunohistochemical studies have indicated that fibroblast growth factor (FGF) receptors rapidly appear on the apical surfaces of supporting cells in the basilar papilla in response to noise trauma in vivo (Lee and Cotanche, 1996). In vitro studies have also shown that activation of a cyclic AMP (cAMP)-dependent protein kinase A-mediated signaling pathway can stimulate a proliferative response in the avian basilar papilla and that protein kinase A inhibitors can block drug damage-induced cell proliferation (Navaratnam et al., 1996). Thus there is evidence that both cAMP and growth factor-mediated pathways can control supporting-cell proliferation, but knowledge of the signaling pathways leading to hair-cell regeneration in vivo is both limited and fragmentary.

We have recently identified a monoclonal antibody $(\mathrm{mAb})$ that selectively stains the apical surface of supporting cells within the sensory epithelia of the inner ear. The antigen recognized by this $\mathrm{mAb}$ is referred to as the supporting-cell antigen (SCA), and cDNA cloning reveals that it is a novel receptor-like protein tyrosine phosphatase (RPTP) [for recent reviews on RPTPs, see Neel and Tonks (1997) and Stoker and Dutta (1998)]. The po- 
tential signaling ability of the SCA and its rapid loss in response to hair-cell damage suggest that it may influence supporting-cell proliferation or hair-cell differentiation in the sensory epithelia of the inner ear.

\section{MATERIALS AND METHODS}

Preparation of monoclonal antibody. Lagenar maculae were dissected from the inner ears of 1- to 3-d-old posthatch chicks in PBS $(150 \mathrm{~mm}$ $\mathrm{NaCl}, 10 \mathrm{~mm}$ sodium phosphate, $\mathrm{pH}$ 7.2) containing $2 \mathrm{~mm}$ benzamidine, $10 \mu \mathrm{M}$ pepstatin, $1 \mu \mathrm{g} / \mathrm{ml}$ leupeptin, and $0.1 \mathrm{~mm}$ phenylmethylsulfonylfluoride, stored under liquid $\mathrm{N}_{2}$ until required, and used to prepare a crude membrane fraction by differential centrifugation. The membrane fraction was suspended in PBS and used to immunize a BALB/c mouse. The mouse was injected three times at 1 month intervals using the material from $\sim 250$ lagenar maculae for each injection. The mouse was then rested for a period of 5 months, boosted with a membrane fraction prepared from $\sim 350$ lagenar maculae, and $7 \mathrm{~d}$ later the spleen was used for the preparation of hybridoma cells using standard techniques (Kohler and Milstein, 1975). Animal procedures were performed in accordance with UK Home Office guidelines. Sp2/O-Ag14 cells were used as the myeloma cell fusion partner, and cells were plated in Costar 24-well plates and selected with hypoxanthine-aminopterin-thymidine growth medium containing 10\% Doma Drive (Immune Systems Ltd., Paignton, UK). Culture supernatants were screened by immunofluorescence microscopy on cryosections of formaldehyde-fixed chick inner ear tissues (see below). Clone D37, secreting monoclonal antibodies that recognize the apical surface of supporting cells, was cloned by limiting dilution on three separate successive occasions to yield monoclonal hybridoma cell line D37.19.1.1 secreting mAb D37. Antibody isotype was determined using a mouse $\mathrm{mAb}$ isotyping kit (Life Technologies Ltd., Paisley, UK). $\mathrm{mAb}$ D37 is an $\operatorname{IgG}_{2 \mathrm{~b}}$ class antibody with $\kappa$ light chains. Concentrations of IgG in tissue culture supernatants were determined by quantitative immunoblotting using mouse $\mathrm{IgG}_{2 \mathrm{~b}}$ purified from the ascites fluid of mice carrying plasmocytoma line MOPC 141 (Sigma, Poole, UK) as a standard.

Immunofluorescence microscopy. To prepare cryostat sections for screening hybridoma supernatants, tissues were immersion-fixed in 3.7\% formaldehyde in $0.1 \mathrm{M}$ sodium phosphate buffer, $\mathrm{pH} 7.4$, for $1 \mathrm{hr}$ at room temperature, washed three times with PBS, cryoprotected by overnight incubation in PBS containing $30 \%$ sucrose at $4{ }^{\circ} \mathrm{C}$, and mounted in $1 \%$ low melting point agar in PBS containing $18 \%$ sucrose. The agar blocks containing the tissue pieces were mounted onto microtome chucks with TissueTek, frozen with Cryospray 134 (Bright Instrument Co. Ltd., Huntingdon, UK), and sections $10 \mu \mathrm{m}$ in thickness were cut at a temperature of $-30^{\circ} \mathrm{C}$. The tissue sections were mounted on gelatin-coated Multitest slides (ICN Biomedicals Ltd., Thame, UK) and stored at $-20^{\circ} \mathrm{C}$ until use. Hybridoma supernatants were applied directly to the sections, and the slides were incubated in a humid chamber overnight. The slides were washed three times in Tris-buffered saline (TBS) (150 $\mathrm{mm} \mathrm{NaCl}, 10 \mathrm{~mm}$ Tris-HCl, $\mathrm{pH}$ 7.4), and bound antibodies were detected by staining sequentially with two layers of FITC-conjugated secondary antibodies, FITC-conjugated rabbit anti-mouse Ig followed by FITCconjugated swine anti-rabbit Ig (Dako, High Wycombe, UK), both diluted 1:100 in TBS containing 10\% horse serum (TBS/HS).

Cryosections for detailed morphological analysis were prepared in the same manner except that $0.025 \%$ glutaraldehyde was added to the fixative to enhance tissue preservation, and the sections were preblocked by incubating them in TBS/HS for $1 \mathrm{hr}$ before the addition of the primary antibody. Whole-mount preparations were fixed in $3.7 \%$ formaldehyde in $0.1 \mathrm{M}$ sodium phosphate for $1 \mathrm{hr}$ at room temperature, washed in PBS, and then preblocked and permeabilized in TBS/HS containing $0.1 \%$ Triton X-100 for $1 \mathrm{hr}$ before use. Polyclonal rabbit antibodies to the tight junction-associated protein cingulin were a kind gift from Dr. Sandra Citi (Universita' di Padova, Italy) (Citi et el., 1988). These antibodies stain the tight junctions around the apex of the cells and were used to clearly define the boundaries between adjacent cells. Monoclonal $\mathrm{IgG}_{1}$ antibody to the $275 \mathrm{kDa}$ hair-cell antigen (HCA) has been described previously (Richardson et al., 1990). For double labels with monoclonal anti-HCA and $\mathrm{mAb}$ D37, after labeling with a mixture of the two hybridoma supernatants both diluted 1:10 in TBS/HS, samples were incubated sequentially in (1) a mixture of FITC-conjugated sheep anti-mouse $\mathrm{IgG}_{2 \mathrm{~b}}$ (Serotec, Kidlington, UK) and unlabeled rabbit anti-mouse $\mathrm{IgG}_{1}$ (Zymed, Cambridge, UK), (2) FITC-conjugated donkey anti-sheep Ig (Sigma), and (3) rhodamine-conjugated swine anti-rabbit Ig. For double labels with mAb D37 and rabbit anti-cingulin, after labeling with mAb D37 supernatant (1:10 dilution) containing rabbit anti-cingulin at a dilution of 1:1000, the samples were incubated sequentially in (1) rhodamine-conjugated swine anti-rabbit Ig, (2) FITC-conjugated sheep anti-mouse $\mathrm{IgG}_{2 \mathrm{~b}}$, and (3) FITC-conjugated donkey anti-sheep Ig. To triple-label with $\mathrm{mAb} \mathrm{D} 37$, monoclonal anti-HCA, and rabbit anticingulin, after labeling with a mixture of the two monoclonal supernatants (both at 1:10 dilution) containing rabbit anti-cingulin at a dilution of 1:1000, the samples were incubated sequentially in (1) a mixture of FITC-conjugated sheep anti-mouse $\mathrm{IgG}_{2 \mathrm{~b}}$ and unconjugated rabbit antimouse $\mathrm{IgG}_{1}$, (2) FITC-conjugated donkey anti-sheep Ig, and (3) rhodamine-conjugated swine anti-rabbit Ig. This procedure enabled the HCA and cingulin to be observed simultaneously through the rhodamine channel and the SCA to be observed through the FITC channel. All secondary antibodies were used at a dilution of $1: 100$ in TBS/HS. To visualize F-actin, tetramethyl rhodamine isothiocyanate-phalloidin was added to the secondary antibodies at a concentration of $20 \mathrm{ng} / \mathrm{ml}$. To improve permeability of the anti-cingulin and secondary antibodies in whole mounts, all solutions additionally contained $0.1 \%$ Triton X-100. As a control for the immunofluorescence procedure with mAb D37, samples were stained with an irrelevant mouse $\operatorname{IgG}_{2 b}$ (MOPC 141) at a concentration of $5 \mu \mathrm{g} / \mathrm{ml}$, a concentration 2.5 -fold higher than that present in the diluted mAb D37 tissue culture supernatant.

Immunoelectron microscopy. Inner ear and eye tissues were dissected in PBS and immersion-fixed in $3.7 \%$ formaldehyde $/ 0.025 \%$ glutaraldehyde in $0.1 \mathrm{M}$ sodium phosphate buffer for $1 \mathrm{hr}$ at room temperature. Tissue samples were then washed three times with PBS, preblocked with TBS/HS for $1 \mathrm{hr}$, and incubated in mAb D37 tissue culture supernatant (1:10 dilution) overnight at $4^{\circ} \mathrm{C}$. Samples were then washed extensively with $\mathrm{TBS} / 0.05 \%$ Tween, incubated in rabbit anti-mouse $\operatorname{IgG}_{2 \mathrm{~b}}$ diluted 1:100 in TBS/HS $/ 0.05 \%$ Tween overnight at $4^{\circ} \mathrm{C}$, washed again with TBS $/ 0.05 \%$ Tween, and incubated in $10 \mathrm{~nm}$ gold-conjugated rabbit anti-mouse Ig (British BioC ell International Ltd., Cardiff, UK) overnight at $4^{\circ} \mathrm{C}$. After gold labeling, samples were washed five times with TBS/ $0.5 \%$ Tween, five times with PBS, fixed with $2.5 \%$ glutaraldehyde in 0.1 M sodium cacodylate buffer, $\mathrm{pH} 7.4$ for $1 \mathrm{hr}$, washed with cacodylate buffer, and post-fixed with $1 \% \mathrm{OsO}_{4}$ in $0.1 \mathrm{~m}$ sodium cacodylate buffer for $1 \mathrm{hr}$. Samples were then washed briefly in $\mathrm{H}_{2} \mathrm{O}$, dehydrated through a series of ascending concentrations of ethanol, equilibrated with propylene oxide, and embedded in Epon 812 resin. Blocks were cured for $2 \mathrm{~d}$ at $60^{\circ} \mathrm{C}$ and sectioned at a thickness of $90 \mathrm{~nm}$. Sections were counterstained with uranyl acetate and lead citrate and viewed in a Hitachi transmission electron microscope. Samples incubated either in hybridoma medium that had not been used for cell growth or irrelevant monoclonal supernatant (mAb E40) (Goodyear and Richardson, 1999) diluted 1:10 were used as controls for the immunogold-labeling procedure.

Western blotting. Frozen tissue samples were thawed on ice, homogenized, and sequentially extracted in $1 \mathrm{ml}$ vol of ice-cold TBS, high-salt buffer $(1.0 \mathrm{M} \mathrm{NaCl}, 10 \mathrm{~mm}$ Tris-HCl, pH 7.4), low-salt buffer $(10 \mathrm{~mm}$ Tris-HCl, pH 7.4), and Triton X-100 (1\% Triton X-100 in $10 \mathrm{~mm}$ Tris-HCl, pH 7.4). All buffers contained a mixture of protease inhibitors ( $2 \mathrm{~mm}$ benzamidine, $10 \mu \mathrm{M}$ pepstatin, $1 \mu \mathrm{g} / \mathrm{ml}$ leupeptin, $1 \mathrm{~mm}$ phenylmethylsulfonylfluoride, and $2 \mathrm{~mm} N$-ethyl maleimide). The homogenates were centrifuged for $15 \mathrm{~min}$ at $100,000 \mathrm{rpm}$ in a TLA100 rotor using a Beckman TLS benchtop ultracentrifuge to produce soluble, high-saltsoluble, low-salt-soluble, Triton X-100-soluble, and insoluble fractions. The soluble, high-salt-soluble, and low-salt-soluble fractions were precipitated by adding TCA to a final concentration of $20 \%$ and leaving them on ice for $30 \mathrm{~min}$. The Triton X-100-soluble fraction was precipitated by adding 9 vol of cold acetone and holding it at $-20^{\circ} \mathrm{C}$ for $30 \mathrm{~min}$. Precipitated proteins were collected by centrifugation, solubilized in reducing SDS-PAGE sample buffer, boiled for $4 \mathrm{~min}$, and run on $7.5 \%$ acrylamide gels. To visualize proteins the gels were stained with Coomassie brilliant blue. For immunoblotting, the separated proteins were transferred to nitrocellulose by semi-dry electrophoresis. The nitrocellulose blots were preblocked with 3\% Marvel in TBS containing $0.05 \%$ Tween for $1 \mathrm{hr}$, incubated overnight with rabbit antibodies (1:100 dilution in preblock solution) or mAb D37 supernatant, washed with TBS/ $0.05 \%$ Tween, and then incubated in alkaline phosphatase-conjugated rabbit anti-mouse Ig or alkaline phosphatase-conjugated goat anti-rabbit Ig for $2 \mathrm{hr}$. After washes with TBS $/ 0.05 \%$ Tween, blots were rinsed briefly with alkaline phosphatase buffer $\left(0.1 \mathrm{M} \mathrm{NaCl}, 0.05 \mathrm{M} \mathrm{MgCl}_{2}, 0.1\right.$ $\mathrm{M}$ Tris-HCl, $\mathrm{pH} 9.5$ ) and reacted with alkaline phosphatase buffer containing $0.34 \mathrm{mg} / \mathrm{ml}$ nitroblue tetrazolium and $0.175 \mathrm{mg} / \mathrm{ml}$ 5-bromo-4- 
chloro-3-indolyl phosphate. Tissue culture supernatants containing irrelevant monoclonal antibody (mAb E40) (Goodyear and Richardson, 1999) or rabbit preimmune serum diluted 1:100 were used as controls for the immunoblotting procedures.

Preparation of a chick intestine $c D N A$ library. Poly $(\mathrm{A})^{+}$RNA was prepared from the small intestine of 2-d-old posthatch chicks using a Quick-Prep micro kit (Pharmacia, Milton Keynes, UK). First-strand cDNA synthesis was primed with a mixture of random hexamers (Promega, Southampton, UK). The resultant single-strand cDNA was rendered double-stranded and, after the addition of EcoRI adaptors, ligated into the EcoRI site of the $\lambda$ Zap II vector (Stratagene, Cambridge, UK). The cDNA library was amplified before screening.

Isolation of $c D N A$ clones. A total of $1.5 \times 10^{6}$ clones was immunoscreened with mAb D37 using alkaline phosphatase-conjugated goat anti-mouse IgG to detect immunopositive plaques. A single phage clone was isolated through three successive rounds of immunoscreening and converted to a plasmid (pBluescript $\mathrm{SK}^{+}$) by helper phage rescue. Additional clones encoding the entire open reading frame were isolated by high-stringency screening with ${ }^{32} \mathrm{P}$-labeled DNA probes (see below) derived from the initial immunopositive clone by PCR amplification with sequence-specific primers.

Preparation of ${ }^{32} \mathrm{P}$-labeled probes. PCR products were generated from cDNA clones, separated by gel electrophoresis, purified from the gel using GeneClean (Stratatech Scientific, Luton, UK) and random primerlabeled (Feinberg and Vogelstein, 1984) with $\alpha^{32}$ P-dCTP using a MegaPrime labeling kit (Amersham International, Little Chalfont, UK). Unincorporated label was removed using Sephadex G50 columns (Pharmacia), and the probes were denatured before they were added to the hybridization mix.

DNA sequencing and analysis. Double-stranded plasmid DNA was prepared using Wizard Plus minipreps (Promega) and sequenced with T7 DNA polymerase by the dideoxy-chain termination method of Sanger et al. (1977) using T3, T7, and specific oligonucleotide primers. Some plasmid DNA samples were also sequenced on an ABI 370A automatic sequencer. Sequence analysis was performed using the DNA Star package (DNA Star, London, UK). Protein and DNA sequence database searches were performed using the BLAST network service at the National Center for Biotechnology Information (Altschul et al., 1997).

Preparation of antibodies to an extracellular domain bacterial fusion protein. Primers with an internal XhoI restriction site (forward F1: CGTACAGGCTCGAGGTTAGGAATGCTACT; reverse R1: CTCCCCTCGAGTTGACTCTGTTGCTT) were used to amplify a $1635 \mathrm{bp}$ fragment from cDNA clone A corresponding to amino acids 294-838 in the extracellular domain of the SCA. The PCR product was separated by gel electrophoresis in a Tris borate-EDTA-agarose gel, recovered from the gel using GeneClean, digested with XhoI, extracted with phenol/ chloroform, and precipitated with ethanol. The PCR product was ligated into a XhoI cut, dephosphorylated pET15b vector (Novagen, Abingdon, UK) using T4 DNA ligase, and transformed into Escherichia coli XL1blue cells. A plasmid containing the cDNA insert in the correct orientation was transformed into $E$. coli BL21 cells, and expression of the His-tagged fusion protein was induced with iso-propyl $\beta$-Dthiogalactopyranoside. The fusion protein was purified from bacterial lysates using His-bind resin (Novagen), dialyzed against $\mathrm{H}_{2} \mathrm{O}$, lyophilized, and resuspended in PBS. A rabbit was immunized with $\sim 0.5 \mathrm{mg}$ of the fusion protein on four separate occasions at 1 month intervals, using Freund's complete adjuvant for the first immunization and Freund's incomplete adjuvant for the later boosts. Antibodies were affinitypurified on a column of the fusion protein coupled to Sepharose 4B (Sigma).

Immunoprecipitation. Triton X-100-soluble fractions were prepared from frozen samples of small intestine, kidney, retina, and utricular maculae as described above for Western blotting using EDTA (2 mM) as an additional protease inhibitor and sodium phosphate (20 mM, pH 7.4) in place of Tris- $\mathrm{HCl}$ to buffer the solutions. Protein content of the extracts was determined using the bicinchoninic acid protein assay reagent (Pierce, Chester, UK). Rabbit immune serum to the extracellular domain fusion protein or preimmune serum $(4 \mu \mathrm{l})$ was added to $400 \mu \mathrm{l}$ aliquots of the extracts, each containing $72 \mu \mathrm{g}$ of protein, and the samples were incubated overnight at $4^{\circ} \mathrm{C}$. Immune complexes were collected by adding a $20 \mu \mathrm{l}$ vol of protein A-agarose beads [prepared as a 1:1 (v/v) suspension in the Triton X-100 extraction buffer] and incubating the samples for $1 \mathrm{hr}$ at $4^{\circ} \mathrm{C}$ on a rotator. The beads were then washed three times with cold PBS containing 1\% Triton X-100 and one time with cold PBS and then boiled in a $15 \mu \mathrm{l}$ vol of reducing SDS-PAGE sample buffer.
Aliquots of the eluted samples $(10 \mu \mathrm{l})$ were run on $7.5 \%$ polyacrylamide gels, transferred to nitrocellulose membranes, and immunoblotted with the mAb D37 supernatant as described above.

$R T$-PCR. Poly $(\mathrm{A})^{+}$mRNA was isolated from chick small intestine, kidney, retina, and utricular macula as described above and used to synthesize randomly primed first-strand cDNA using avian myeloblastosis virus reverse transcriptase (Promega). The resultant cDNA was used in RT-PCR reactions with oligonucleotide primer pairs designed to amplify bases $2887-4310$ of the cDNA sequence (forward F2: CATATGCTCGAGATGACAGCCACCTATGTGAC; reverse R2: GGATCCTCGAGCTTTCTCATGCACAGACAAC). The $50 \mu \mathrm{l}$ reactions contained 50 pmol each primer and were hot-started with $4 \mathrm{U}$ of TaqExpress (Genpak Ltd., Brighton, UK) followed by 35 cycles of $94^{\circ} \mathrm{C}$ for $15 \mathrm{sec}$, $57^{\circ} \mathrm{C}$ for $15 \mathrm{sec}$, and $68^{\circ} \mathrm{C}$ for $90 \mathrm{sec}$. The reactions were terminated with a $5 \mathrm{~min}$ incubation at $68^{\circ} \mathrm{C}$. PCR reactions were analyzed by agarose gel electrophoresis followed by transfer to Hybond-N membrane (Amersham International) and UV cross-linking. Membranes were then hybridized with a ${ }^{32} \mathrm{P}$-labeled DNA probe derived by PCR of cDNA clone $\mathrm{C}$ with primers lying internal to those used for the RT-PCR reactions (forward F3: ACACAATGGAGAGCCACACA; reverse R3: TCCATGACACACTGGTTTAG). Hybridization of the membranes and washing to high stringency were performed as described by the manufacturer (Amersham International). In addition the $1.4 \mathrm{kbp}$ product was purified using GeneClean and directly sequenced on an ABI 370A automatic sequencer to confirm its identity in all four tissues.

Preparation of noise- and drug-damaged auditory papillae. One-weekold chicks were exposed to $120 \mathrm{~dB}$ sound pressure level (SPL) octave band noise centered around a frequency of $2.0 \mathrm{kHz}$ for $14 \mathrm{hr}$ and killed $1 \mathrm{hr}$ after the end of the exposure period [see Raphael (1993) for a description of the noise exposure setup]. Also, 2-week-old chicks were exposed to a $900 \mathrm{~Hz}$ tone at $120 \mathrm{~dB}$ SPL for $12 \mathrm{hr}$ and killed $4 \mathrm{hr}$ after the end of the exposure period [for details, see Cotanche et al. (1995)]. Pieces of skull containing the labyrinth were immersion-fixed as described above, basilar papillae were dissected, and whole-mount preparations were double-labeled with monoclonal anti-HCA and mAb D37, or triple-labeled with monoclonal anti-HCA, mAb D37, and cingulin, as described earlier. Papillae from a total of eight noise-damaged animals and three age-matched controls were examined. The noise exposure procedures and animal handling were approved by the University of Michigan's Committee on the Use and Care of Animals (UCUCA, approval 6981A) and the Institutional Animal Care and Use Committee at The Children's Hospital (Boston, MA) and were performed in a manner consistent with the National Institutes of Health Guide for Care and Use of Laboratory Animals.

Basilar papillae from 14-d-old posthatch chicks were dissected in Medium 199 with HBSS and additional HEPES buffer and placed in MatTek culture wells in Medium 199 with Earle's salts supplemented with $10 \%$ fetal bovine serum. To induce hair-cell loss, neomycin was added to a final concentration of either 0.2 or $1.0 \mathrm{~mm}$. Cultures were maintained for $24 \mathrm{hr}$ in vitro at $37^{\circ} \mathrm{C}$ in an atmosphere of $95 \%$ air $/ 5 \%$ $\mathrm{CO}_{2}$, washed with serum-free medium, and fixed in $4 \%$ paraformaldehyde buffered with $0.1 \mathrm{M}$ sodium phosphate, $\mathrm{pH} 7.2$, for $30 \mathrm{~min}$. Cultures were then washed in PBS and prepared for cryosectioning as described above, and 20- $\mu \mathrm{m}$-thick sections were cut in a plane parallel to the apical surface of the papilla. Sections were triple-labeled for the HCA, SCA, and cingulin as described above. A total of eight papillae exposed to 1.0 $\mathrm{mm}$ neomycin, three exposed to $0.2 \mathrm{~mm}$ neomycin, and eight unexposed controls were examined.

\section{RESULTS}

\section{mAb D37 recognizes a Triton $\mathrm{X}-100$-soluble protein of $\sim 220 \mathrm{kDa}$ present on the apical surface of supporting cells}

Whole mounts of the posthatch basilar papilla double-labeled with mAb D37 and monoclonal anti-HCA reveal that mAb D37 specifically stains the narrow, compacted apical surfaces of the supporting cells that surround each hair cell but not the apical surfaces of the hair cells (Fig. 1a, $a^{\prime}$ ). Cryosections of the cochlear duct that have been double-labeled with mAb D37 and rhodaminephalloidin show that the apical surface of the basilar papilla is 

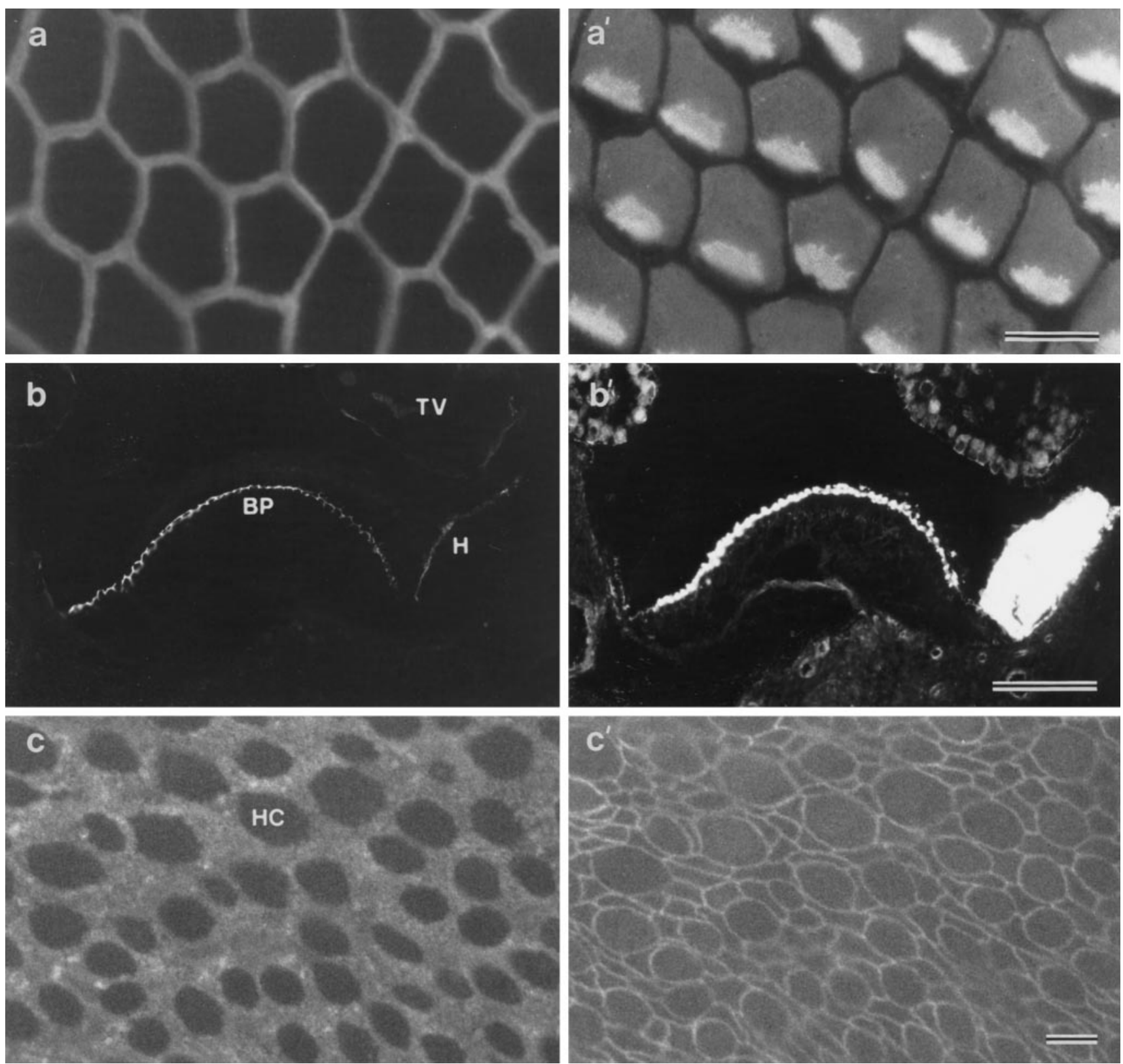

Figure 1. $a, a^{\prime}$, A whole-mount preparation of the basilar papilla double-labeled with mAb D37 $(a)$ and monoclonal anti-hair cell antigen $\left(a^{\prime}\right)$. The image is focused on the apical surface of the epithelium, in an area from the inferior region of the papilla where the short hair cells are located. MAb D37 stains the narrow compacted surfaces of the supporting cells that surround each hair cell. The anti-HCA mAb stains the base of the hair bundle and most of the apical, nonstereociliary surface of the cell except for a small patch lying behind the hair bundle where the kinocilium is located. $b, b^{\prime}$, A cryosection of the basilar papilla double-labeled with mAb D37 $(b)$ and rhodamine-phalloidin $\left(b^{\prime}\right)$ to reveal the distribution of the SCA and F-actin, respectively. Note how the surface of the basilar papilla $(B P)$ is intensely stained by mAb D37. Staining is also observed on the surfaces of the homogene cells $(H)$. The lumenal surface of the tegmentum vasculosum $(T V)$ is only very weakly labeled. $c, c^{\prime}$, A whole-mount preparation of the utricular macula double-labeled with mAb D37 to reveal the distribution of the SCA $(c)$ and rabbit anti-cingulin to distinguish the boundaries of the cells $\left(c^{\prime}\right)$. The apical surfaces of the hair cells $(H C)$ are not labeled by mAb D37 and appear as dark holes (c). Scale bars: $a, a^{\prime}, c, c^{\prime}, 10 \mu \mathrm{m} ; b, b^{\prime}, 100 \mu \mathrm{m}$.

intensely stained by the antibody (Fig. $1 b, b^{\prime}$ ). Labeling is also observed on the apical surfaces of the homogene cells and, to a much lower extent, on the lumenal surface of the cells in the tegmentum vasculosum (Fig. 1b). Cryosections also indicate that mAb D37 labeling is restricted to the apical surface of cells in the cochlear duct; staining is not observed on the basolateral membranes of cells in these epithelia. mAb D37 also reacts with the apical surfaces of supporting cells in the vestibular epithelia of the inner ear, where the supporting-cell surfaces are larger and less regular in shape and size than they are in the basilar papilla (Fig. 1c, $c^{\prime}$ ).

The mAb D37 reacts with a protein band of $220 \mathrm{kDa}$ (Fig. 2) on immunoblots of protein fractions prepared from the lagenar macula, a vestibular organ found at the end of the cochlear duct. Immunoreactivity is not detected in either the soluble or low-saltsoluble fractions. Traces of immunoreactive protein can be detected in the high-salt-soluble fraction, and a large proportion of the $220 \mathrm{kDa}$ protein is soluble in the nonionic detergent Triton 
a

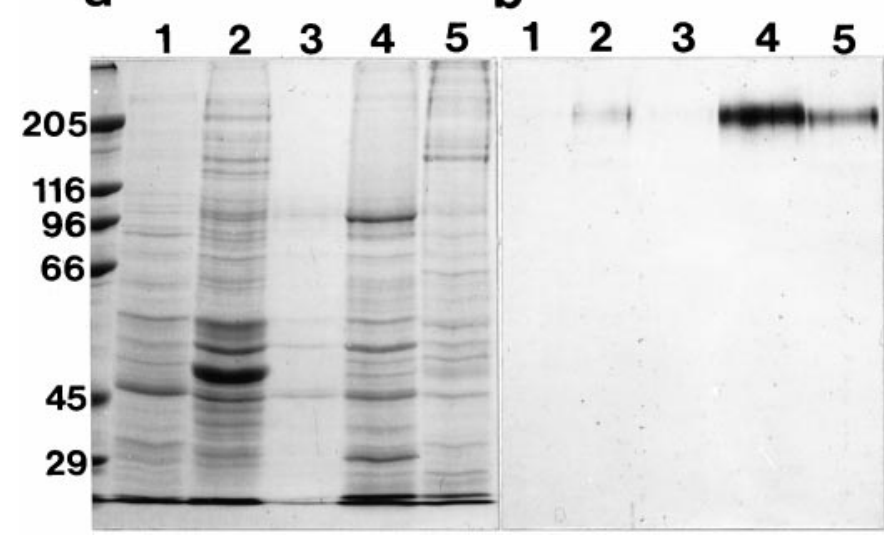

Figure 2. $a, b$, Coomassie brilliant blue-stained gel $(a)$ and an immunoblot stained with mAb D37 (b) of soluble (1), high-salt-soluble (2), low-saltsoluble (3), Triton X-100-soluble (4), and insoluble (5) fractions prepared from lagenar maculae. Lanes 1 and 5 contain protein from the equivalent of two lagenar maculae; lanes 2-4 contain protein from 10 lagenar maculae.

$\mathrm{X}-100$. However, significant amounts of the protein are found in the insoluble fraction that remains after extraction with Triton $\mathrm{X}-100$ (Fig. 2). Because the $220 \mathrm{kDa}$ protein recognized by $\mathrm{mAb}$
D37 is localized on the apical surfaces of supporting cells within the sensory epithelia of the inner ear, it is referred to as the SCA.

\section{mAb D37 also recognizes the apical membranes of epithelial cells in kidney, gut, and retina}

Cryosections of brain, gizzard, heart, intestine, kidney, liver, lung, skeletal muscle, and retina were screened for immunoreactivity with $\mathrm{mAb}$ D37. Staining was not detected in brain, gizzard, heart, liver, lung, or muscle. In the intestine, kidney, and retina strong immunoreactivity was observed (Fig. $3 b-d$ ). As in the basilar papilla (Fig. 3a), the staining seen in these tissues with mAb D37 is associated with the apical surfaces of the epithelia (Fig. $3 b-d$ ). In the kidney and intestine, mAb D37 stains the brush borders (Fig. $3 b, c$ ), and in the retina it stains the external limiting membrane (Fig. $3 d$ ). Specific immunostaining was not observed when cryosections of basilar papilla, kidney, intestine, and retina were stained with an irrelevant mouse $\mathrm{IgG}_{2 \mathrm{~b}}$ monoclonal antibody at a concentration 2.5-fold higher than that estimated to be present in the diluted mAb D37 supernatants (Fig. $3 e-h$ ).

Immunoelectron microscopy reveals that the epitope recognized by mAb D37 is located on the external surface of the plasma membrane (Fig. 4). In the ear, the antigen is associated with the microvillar and nonmicrovillar membrane of the supporting-cell surface (Fig. $4 a$ ). The SCA is not present on the kinocilia of the supporting cells (Fig. $4 a$ ). In the retina, the SCA
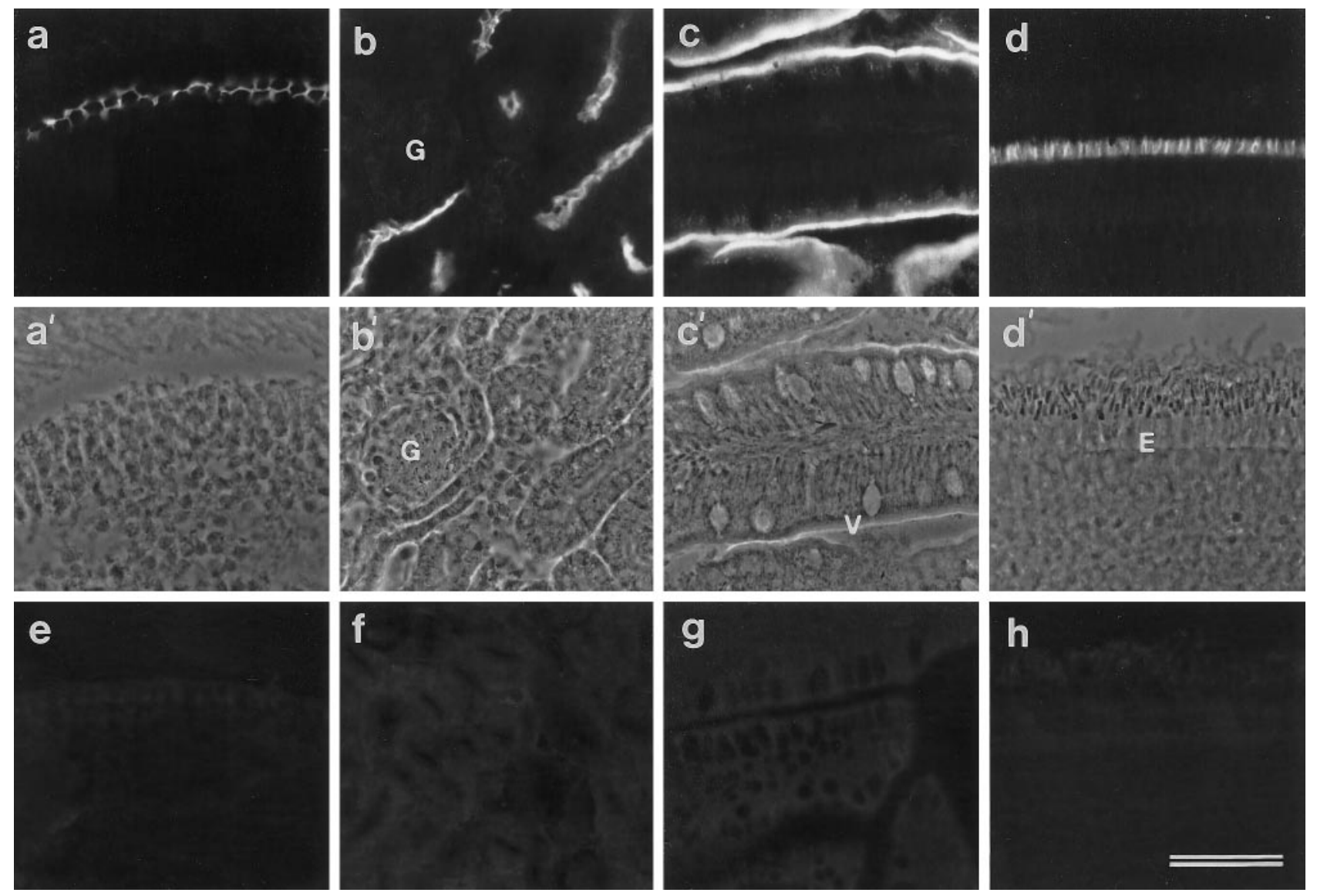

Figure 3. Immunofluorescence micrographs $(a-d)$ and the corresponding phase-contrast images $\left(a^{\prime}-d^{\prime}\right)$ of cryosections from the basilar papilla $(a)$, kidney $(b)$, intestine $(c)$, and retina $(d)$ stained with $\mathrm{mAb}$ D37. In $a$, the surfaces of the supporting cells in the basilar papilla give a honeycomb staining pattern. In $b$, the brush borders of tubules in the kidney are stained but the glomerulus $(G)$ is unstained. In $c$, the brush borders of the intestinal villi $(V)$ are stained, and in $d$, the external limiting membrane $(E)$ marking the boundary of the outer nuclear layer is stained. $e-h$, Immunofluorescence micrographs of cryosections of basilar papilla $(e)$, kidney $(f)$, intestine $(g)$, and retina $(h)$ stained with an irrelevant $\operatorname{IgG}_{2 \mathrm{~b}} \mathrm{mAb} \mathrm{MOPC}_{141}$. Scale bar, $50 \mu \mathrm{m}$ (applies to $a-h)$. 

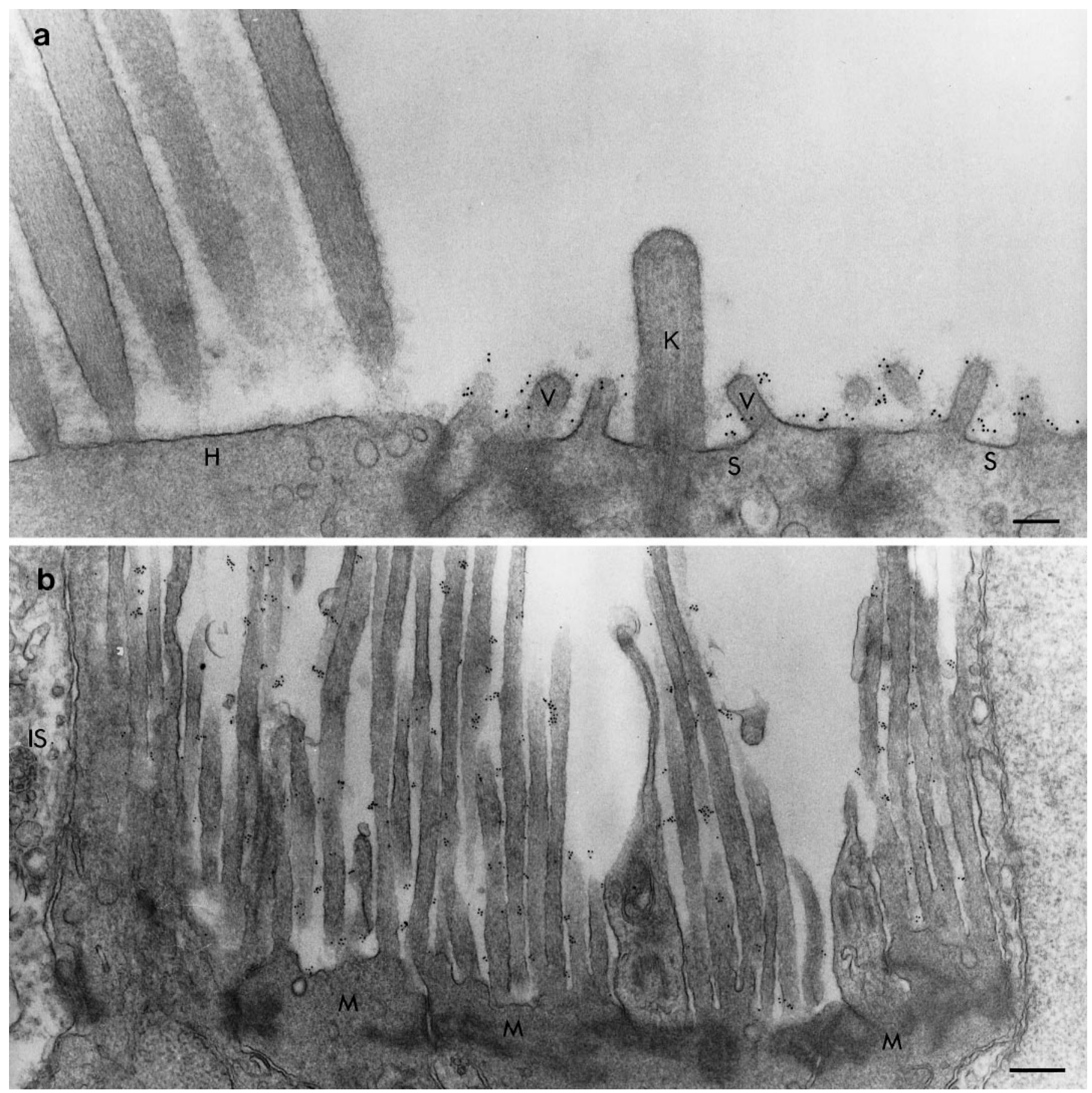

Figure 4. $a, b$, Electron micrographs of the utricular macula $(a)$ and retina $(b)$ immunolabeled with $\mathrm{mAb}^{\mathrm{D} 37}$, rabbit anti-mouse $\mathrm{IgG}_{2 \mathrm{~b}}$, and $10 \mathrm{~nm}$ gold-conjugated goat anti-rabbit Ig before imbedding. $a$, Gold particles are associated with the apical surfaces of the supporting cells $(S)$ and their microvilli $(V)$ but not the kinocilium $(K)$. The apical surface of the hair cell $(H)$ is unlabeled. $b$, In the retina the gold particles are present on the long microvilli emanating from the Müller cells $(M)$ but are not found on the inner segments of the photoreceptors $(I S)$. Scale bars: $a$, $200 \mathrm{~nm} ; b, 400 \mathrm{~nm}$.

is distributed along the microvilli of the Müller cells that surround the photoreceptors to form the external limiting membrane (Fig. 4b). Gold labeling of supporting cell surfaces and Müller cell microvilli was not observed when the primary antibody was omitted or irrelevant mAb supernatant was used in place of mAb D37.

Immunoblots of Triton X-100-soluble fractions prepared from the lagenar macula, kidney, intestine, and retina reveal that $\mathrm{mAb}$ D37 recognizes bands of similar but not identical apparent molecular mass in all four tissues (Fig. $5 a$ ). The size of the band varies from $205 \mathrm{kDa}$ in the retina to $270 \mathrm{kDa}$ in the intestine, as determined by back-extrapolating from the highest molecular size marker used (myosin, $205 \mathrm{kDa}$ ). Single bands are consistently observed in fractions prepared from maculae $(220 \mathrm{kDa})$, retina $(205 \mathrm{kDa})$, and kidney $(230 \mathrm{kDa})$, and up to three bands can be detected in the intestinal fraction $(270,240,220 \mathrm{kDa})$. These differences in the apparent molecular mass of the antigen found in the different tissue types are observed consistently from one preparation to another and may result from variations in post- 
a
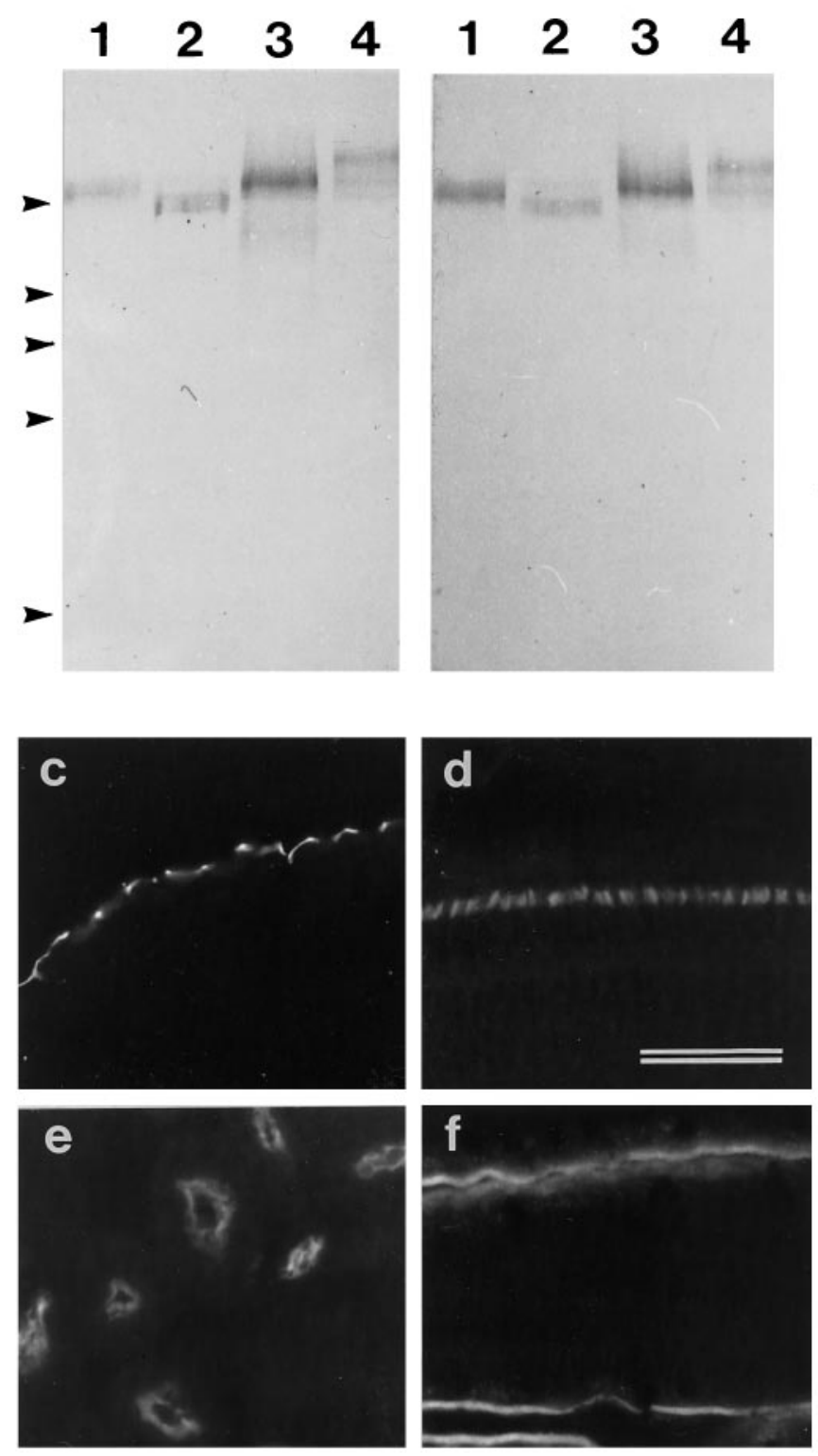

g

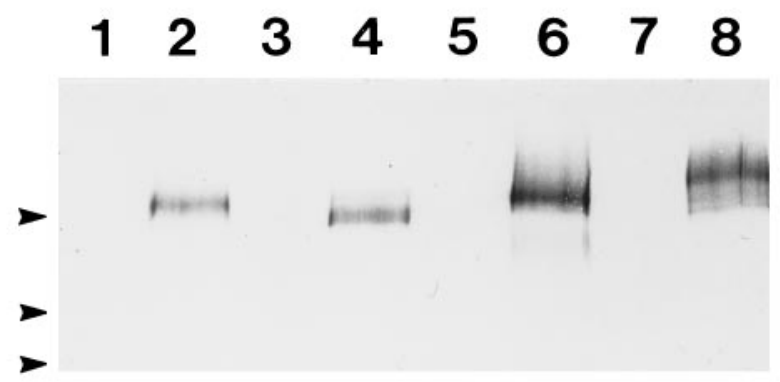

Figure 5. $\quad a, b$, Immunoblots of Triton X-100-soluble fractions prepared from the lagenar macula (1), retina (2), kidney (3), and intestine (4) that have been stained with mAb D37 $(a)$ and affinity-purified rabbit antibodies raised to a bacterially expressed fusion protein containing part of the extracellular domain of the SCA $(b)$. Arrowheads indicate the positions of translational modification in the different tissues or from the presence of alternative splice variants.

\section{The supporting-cell antigen is a receptor-like protein tyrosine phosphatase}

An immunoscreen of a randomly primed chick intestine cDNA library with mAb D37 resulted in the isolation of a single immunopositive clone, clone $\mathrm{A}$, which is $2.3 \mathrm{kbp}$ in size and contains an

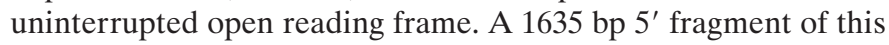
clone was used to generate a bacterial fusion protein of 545 amino acids for the preparation of polyclonal antibodies. The rabbit immune serum directed against this fusion protein stained bands of 205-270 kDa with electrophoretic mobilities the same as those recognized by $\mathrm{mAb}$ D37 in Triton X-100-soluble fractions prepared from the lagenar macula, retina, kidney, and intestine (Fig. $5 a, b)$. This rabbit antiserum also stained cryosections of the inner ear, retina, kidney, and intestine in a manner identical to $\mathrm{mAb}$ D37 (Fig. 5c-f). Although mAb D37 did not react with this fusion protein in immunoblotting (data not shown), the proteins immunoprecipitated from Triton X-100-soluble fractions of lagenar macula, retina, kidney, and small intestine by the polyclonal rabbit serum directed against the fusion protein all reacted with mAb D37 in immunoblots (Fig. 5g). These results provide good evidence that clone A, isolated with mAb D37, encodes the SCA.

Clones encoding the entire open reading frame of the SCA were isolated by screening the library with DNA probes generated by PCR from the 5' and $3^{\prime}$ ends of clone A. Two additional clones, clones AA and $\mathrm{C}$, were obtained. The three clones provide a composite cDNA sequence of $5515 \mathrm{bp}$, with an open reading frame of 4218 bp (Fig. $6 a$ ). The open reading frame encodes a protein of 1406 amino acids (Fig. 6b) with a calculated molecular mass of $154.2 \mathrm{kDa}$. Database searches show that the SCA is a member of the RPTP family, sharing $49.8 \%$ maximal identity with murine Byp (Kuramochi et al., 1996), 48.7\% with rat vascular density-enhanced phosphatase-1 (rDEP-1) (Borges et al., 1996), 45.7\% with human density-enhanced phosphatase (DEP-1) (Östman et al., 1994), and 35.3\% with human PTP $\beta$ (HPTP $\beta$ ) (Krueger et al., 1990). Other RPTPs have considerably less similarity to the SCA. The derived amino acid sequence of the SCA begins with a hydrophobic signal sequence and a region of 58 amino acids that shows no significant similarity to other known proteins. This region is followed by eight highly similar fibronectin type III (FN-III) repeats (Figs. 6b, 7), a membrane proximal region, a hydrophobic transmembrane domain, and a cytoplasmic domain containing the 11 amino acid consensus sequence $[(\mathrm{I} / \mathrm{V}) \mathrm{HCX} \mathrm{AGXXR}(\mathrm{S} / \mathrm{T}) \mathrm{G}]$ for tyrosine phosphatase activity (Fig. 6b,c). This catalytic site is highly conserved and shares $100 \%$ identity with the catalytic sites of human DEP-1 and mouse Byp.

markers with molecular masses (from top to bottom) of 205, 116, 96, 66, and $45 \mathrm{kDa}$. $c-f$, Immunofluorescence micrographs of cryosections from the basilar papilla $(c)$, retina $(d)$, kidney $(e)$, and small intestine $(f)$ that have been stained with the affinity-purified rabbit antibody directed against the extracellular domain of the SCA. The staining patterns are identical to those observed with the mAb D37 shown in Figure 3. Scale bar, $50 \mu \mathrm{m}$. $g$, Immunoblot stained with mAb D37 of proteins immunoprecipitated from Triton X-100-soluble fractions of lagenar macula $(1,2)$, retina $(3,4)$, kidney $(4,5)$, and small intestine $(7,8)$ with rabbit preimmune serum (lanes 1, 3, 5, 7) or rabbit immune serum to the extracellular domain of the SCA (lanes 2, 4, 6, and 8). Arrowheads indicate the positions of markers with molecular masses (from top to bottom) of 205, 116, and $96 \mathrm{kDa}$. 
a

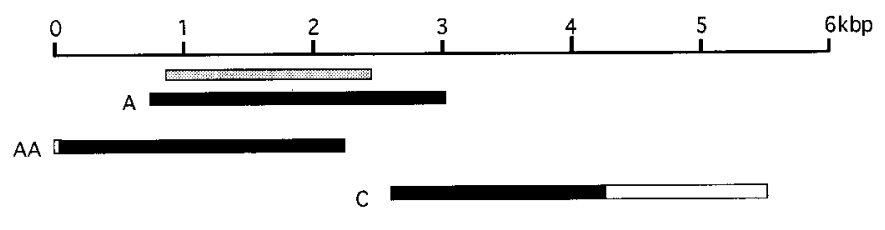

b

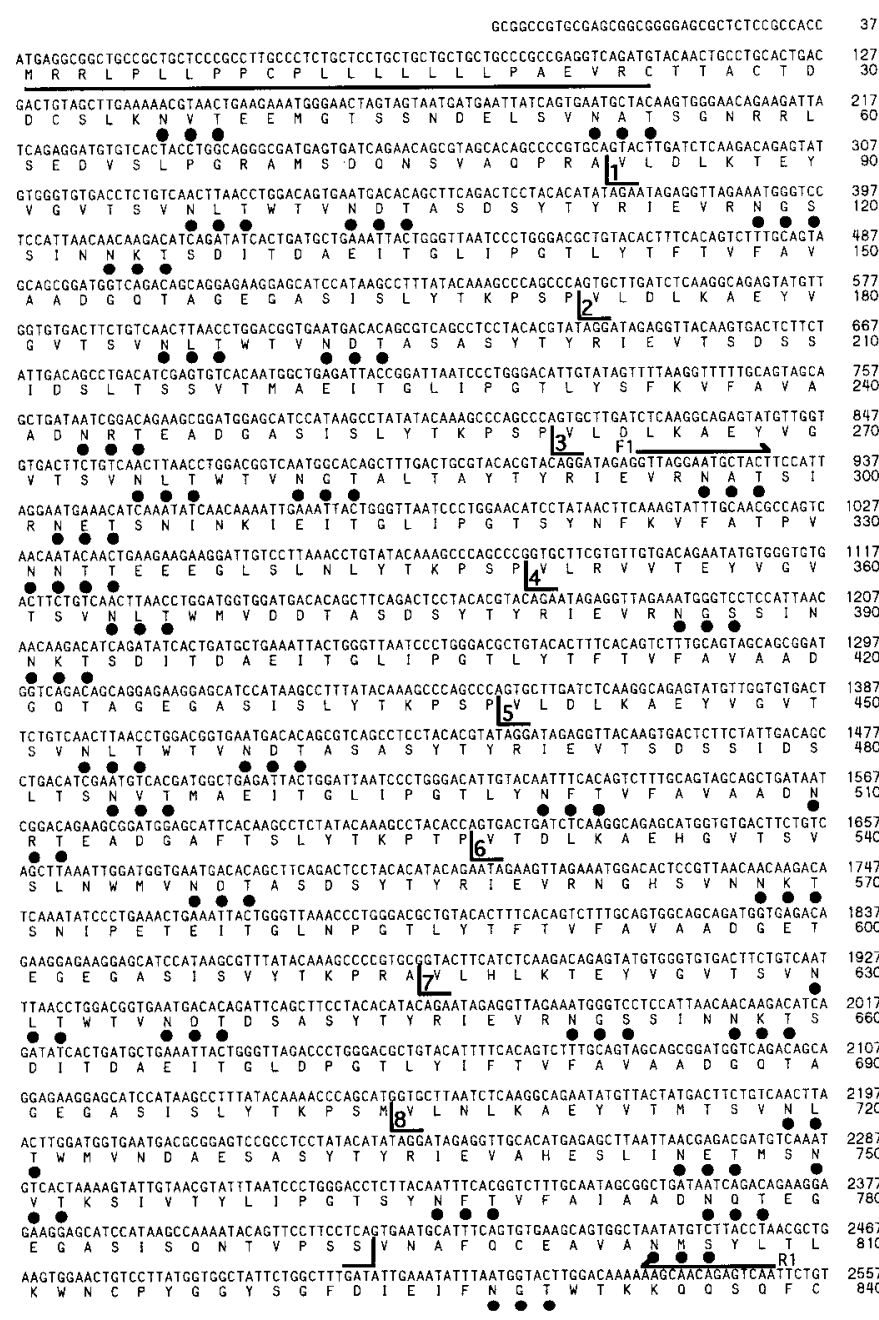

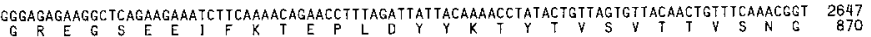

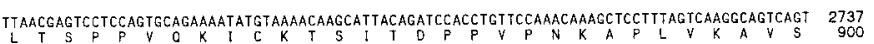

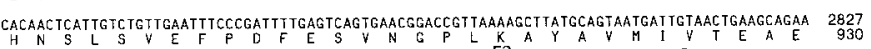

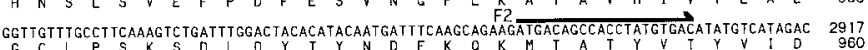

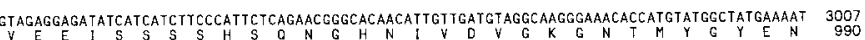

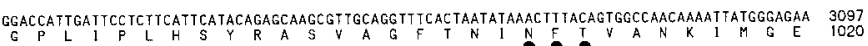
CAAATTATGTGTCATYTTCACCCTGTTCTGAGCTGGTTCATTACCCCAGGATCCAGGTGTATTGCTGGAGCCGTIATTGGATGCCTT 3187

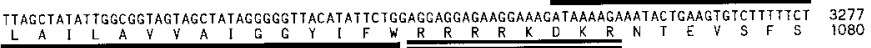

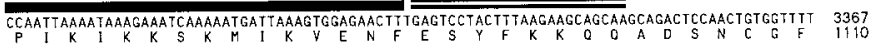

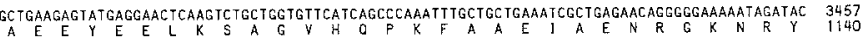

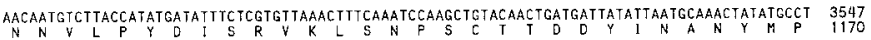

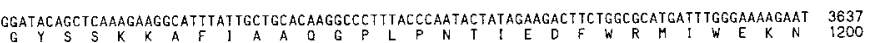

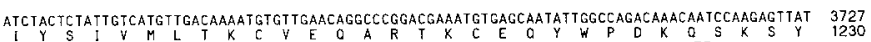

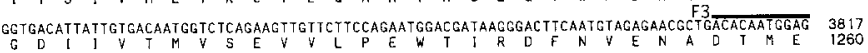

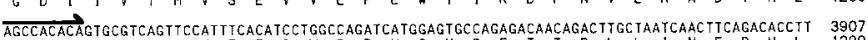
S H T V R O F H F T S W P O H G V P E T T D L L 1 N F R H L 1290

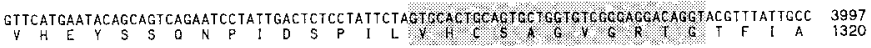

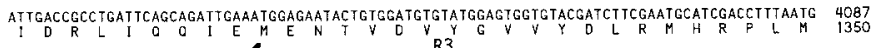

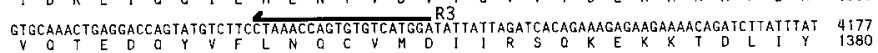

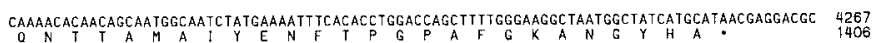
AGCGCAGTCTCTCCAGGAATIGTTGTCTGTGCATGAGAAAGS RAGATGTTCTACTTACATTITCCAGGATIGTGTGCAGTGTCTGGTGTC 4357 TGGTTCICCAGTTCTGTCCTCATATGAaGAagCGATCTTCTGgaggaAaAaAaAgaCAATGCTgGCAgGagCCatggatcgataAaAag 4447

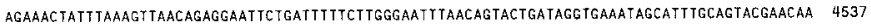

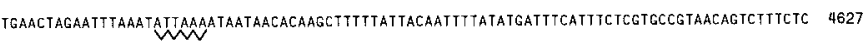
CTACTCC TAAAACACTAATGTITTGTITTTTAAAAGAACACTGGCTTTTAAGAATTGCATCATTTGCATAGCAGAATTACCGTTGTTATC 4717

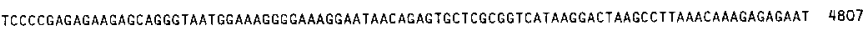

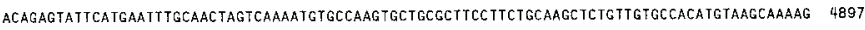

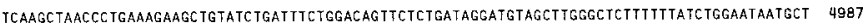

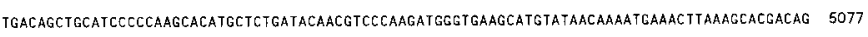
CCAAGTCAGACTAAATCCCTGTITCATCGAGTCCTTCCTTGACTAAAAGACATGGGTTCTGTCICTTGGTAACATACAGAGAAACCAGCA 5167

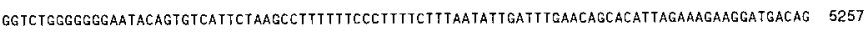

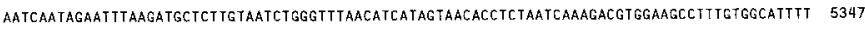

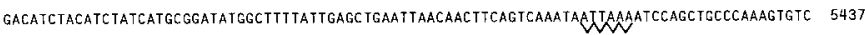

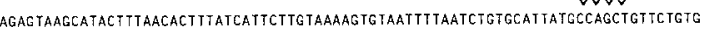
5515

C $500 \quad 1000 \quad 1500$ aa

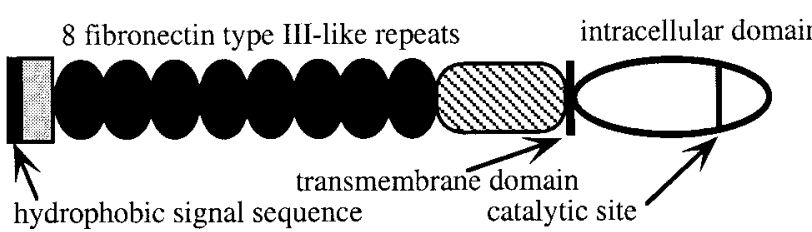

Figure 6. a, A schematic diagram illustrating the relative sizes and positions of the three cDNA clones sequenced to obtain the complete coding region of the SCA. Filled horizontal bars indicate the open reading frame, and open horizontal bars represent the noncoding regions. The region used to make a bacterial fusion protein construct is indicated by the horizontal gray bar. $b$, The cDNA and derived amino acid sequences for the SCA. The hydrophobic leader sequence is underlined, consensus $\mathrm{N}$-glycosylation sites are marked with $\boldsymbol{\bullet}$, the transmembrane domain is underlined in bold, the charged stop transfer sequence is double underlined, and the conserved catalytic site is shaded. The boundaries of the eight FN-III repeats are marked. Positions of the primers used to amplify the fragment used to generate a bacterial fusion protein from the extracellular domain $(F 1, R 1)$, to amplify a region comprising the intracellular domain and the membrane proximal region by RT-PCR $(F 2, R 2)$, and to prepare a probe for Southern screening the resultant RT-PCR products $(F 3, R 3)$ are indicated. $c$, Diagram illustrating the structural organization of the SCA. The hydrophobic signal sequence and the transmembrane domain are indicated by black vertical bars. The lightly shaded rectangle indicates the N-terminal region with no similarity to other proteins, the FN-III repeats are represented by dark ovoids, and the membrane proximal region with similarity to DEP-1 and Byp is shown by the cross-hatching. The intracellular domain is shown by the open ovoid, and the position of the catalytic site within this region is indicated by a vertical line.

RT-PCR with primers designed to amplify a $1.4 \mathrm{kbp}$ region of the cDNA encoding the entire membrane proximal region and the intracellular domain of the protein indicate that the mRNA for the SCA found in the inner ear, retina, kidney, and small intestine is the product of the same gene (Fig. 8). The major PCR product amplified in each of these four tissues was of the size predicted from the intestinal cDNA sequence. These PCR products hybridized at high stringency with an internal probe derived from the intestinal cDNA clone C. Direct sequencing of these PCR products yielded identical sequences from all four tissues. 

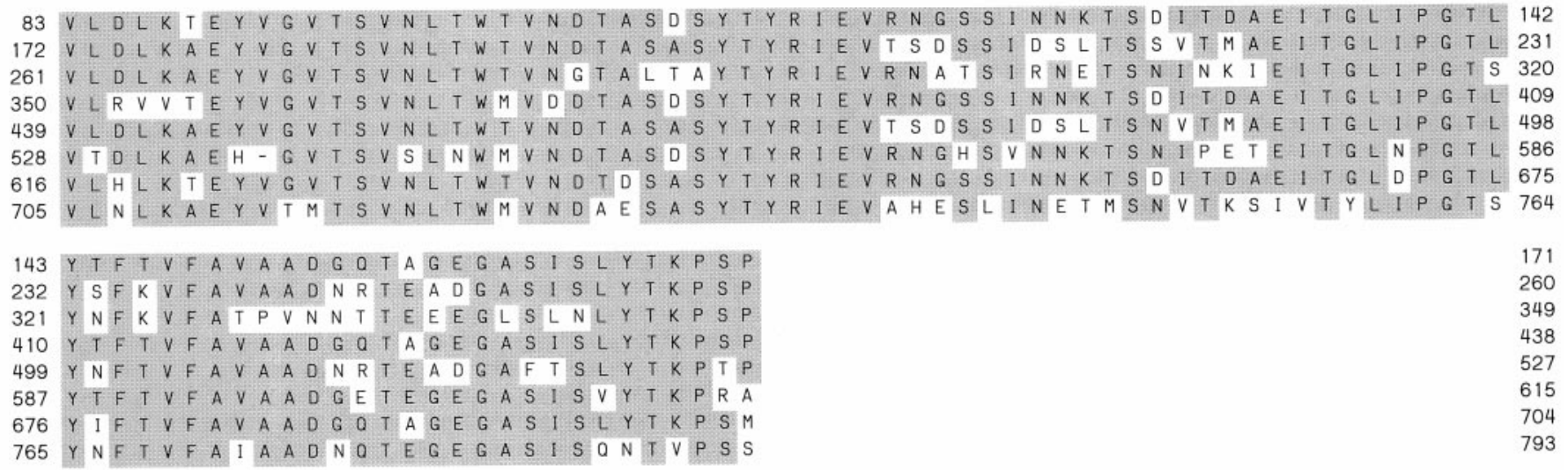

Figure 7. Sequence alignments of the eight fibronectin type III repeats in the extracellular domain of the SCA. Conserved residues are shaded gray. Numbers to the left and right indicate amino acid numbers.

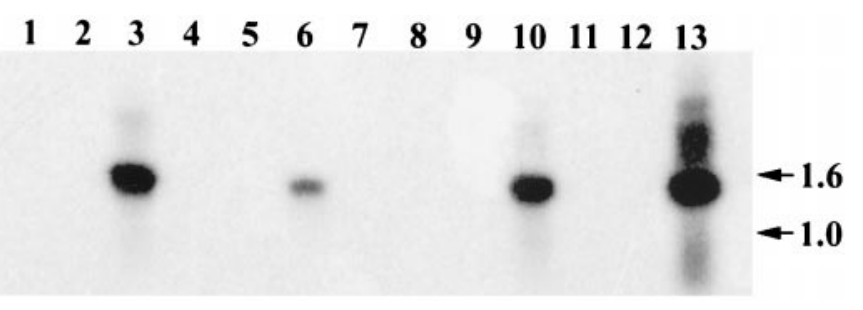

Figure 8 . Southern blot of products obtained by RT-PCR of mRNA from the utricular macula (lanes 1-3), retina (lanes 4-6), kidney (lanes 8-10), and gut (lanes 11-13) using primers designed to amplify a $1.4 \mathrm{kbp}$ product comprising the entire intracellular domain and the membrane proximal region of the SCA. Positions of markers are indicated in kilobase pairs. Lanes 1, 4, 8, and 11 are controls without RNA; lanes 2, 5, 9, and 12 are controls without RT; and lanes 3, 6, 10, and 13 are the products of complete RT-PCR reactions. Size markers were run in lane 7.

RT-PCR with a primer pair designed to amplify the entire extracellular domain including the region encoding the FN-III repeats also amplified a major fragment with the size predicted from the intestinal cDNA clone, but with yields that were insufficient for direct sequencing.

\section{Supporting cells downregulate the SCA in response to noise- and drug-induced hair-cell damage}

In whole-mount preparations of noise-damaged basilar papillae that have been double-labeled with monoclonal anti-HCA and $\mathrm{mAb} \mathrm{D} 37$, it can be seen that the intensity of the mAb D37 labeling on the supporting-cell surfaces decreases in areas of hair-cell damage (Fig. 9). These areas could be readily identified by the disruption of the normal regular mosaic of hair and supporting cells, by supporting cells exhibiting varying degrees of expansion of their apical surface, and the presence of hair cells with small punctate spots of HCA around their perimeter (Fig. 9). Outside the noise-damaged patch, supporting-cell surfaces have characteristic, narrow, compacted surfaces that stain fairly uniformly for the SCA (Fig. 9a, $a^{\prime}$ ). On the edge of and within the damaged patch, some of the supporting cells exhibit substantially lower levels of labeling than neighboring supporting cells (Fig. $\left.9 b, b^{\prime}, c, c^{\prime}\right)$.

In control basilar papillae that have been maintained in vitro for $24 \mathrm{hr}$, the supporting-cell surfaces show a small amount of expansion relative to their in vivo counterparts but otherwise stain intensely for the SCA (Fig. 10a). The hair cells retain a normal morphology (Fig. 10a'). After treatment with $1 \mathrm{~mm}$ neomycin for
$24 \mathrm{hr}$, most hair cells are lost, and in many areas no immunoreactivity can be detected with the monoclonal anti-HCA (Fig. $\left.10 b^{\prime}, c^{\prime}\right)$. In these drug-damaged areas where the hair cells have been lost, although many of the supporting cells maintain high levels of SCA expression, cell surface profiles can be observed that contact one another and do not stain with either mAb D37 or the monoclonal anti-HCA (Fig. 10b-c'). Many of the other supporting cell surfaces have reduced levels of mAb D37 staining relative to those in control cultures.

\section{DISCUSSION}

The results of this study describe the identification and characterization of the SCA as an RPTP that is associated with the apical surface of supporting cells in the sensory epithelia of the inner ear. The SCA is not unique to the inner ear and can be detected by immunofluorescence microscopy in a number of other tissues including retina, intestine, and kidney, where it is also associated with the apical membranes of polarized epithelial cells. The SCA can be detected in the brain by immunoblotting (data not shown) but not by immunofluorescence microscopy, indicating either that it is widely distributed in a diffuse, nonlocalized manner or that the relevant epitope is masked in brain sections. The presence of the SCA in brain is further confirmed by the observation that a partial clone of $\sim 300 \mathrm{bp}$ derived from brain by degenerate RT-PCR has sequence identical to the SCA (Bodden and Bixby, 1996).

The derived amino acid sequence of the SCA predicts a transmembrane protein with a large extracellular domain containing eight FN-III repeats and an intracellular domain with a single catalytic site. The SCA is therefore a class III RPTP, according to the classification system of Tonks and colleagues (Fischer et al., 1991; Brady-Kalnay and Tonks, 1995). A number of other class III RPTPs have been described that only have FN-III repeats in their extracellular domains and a single intracellular catalytic domain. These include the Drosophila RPTPs DPTP10D and DPTP4E (Shin-Shay et al., 1991; Yang et al., 1991), chick CRYP-2 (Bodden and Bixby, 1996), rabbit GLEPP1 (Thomas et al., 1994), murine Byp (Kuramochi et al., 1996), rat DEP-1 (Borges et al., 1996), and, from human, НРТP $\beta$ (Krueger et al., 1990), DEP-1 (Östman et al., 1994), HPTP $\eta$ (Honda et al., 1994), PTP-U2 (Seimiya et al., 1995), and SAP-1 (Matozaki et al., 1994). HPTP $\eta$ and PTP-U2 are 97-99.5\% similar to DEP-1, and all three molecules may therefore be the product of a single gene. The SCA is closely related to murine Byp and to DEP-1 from 

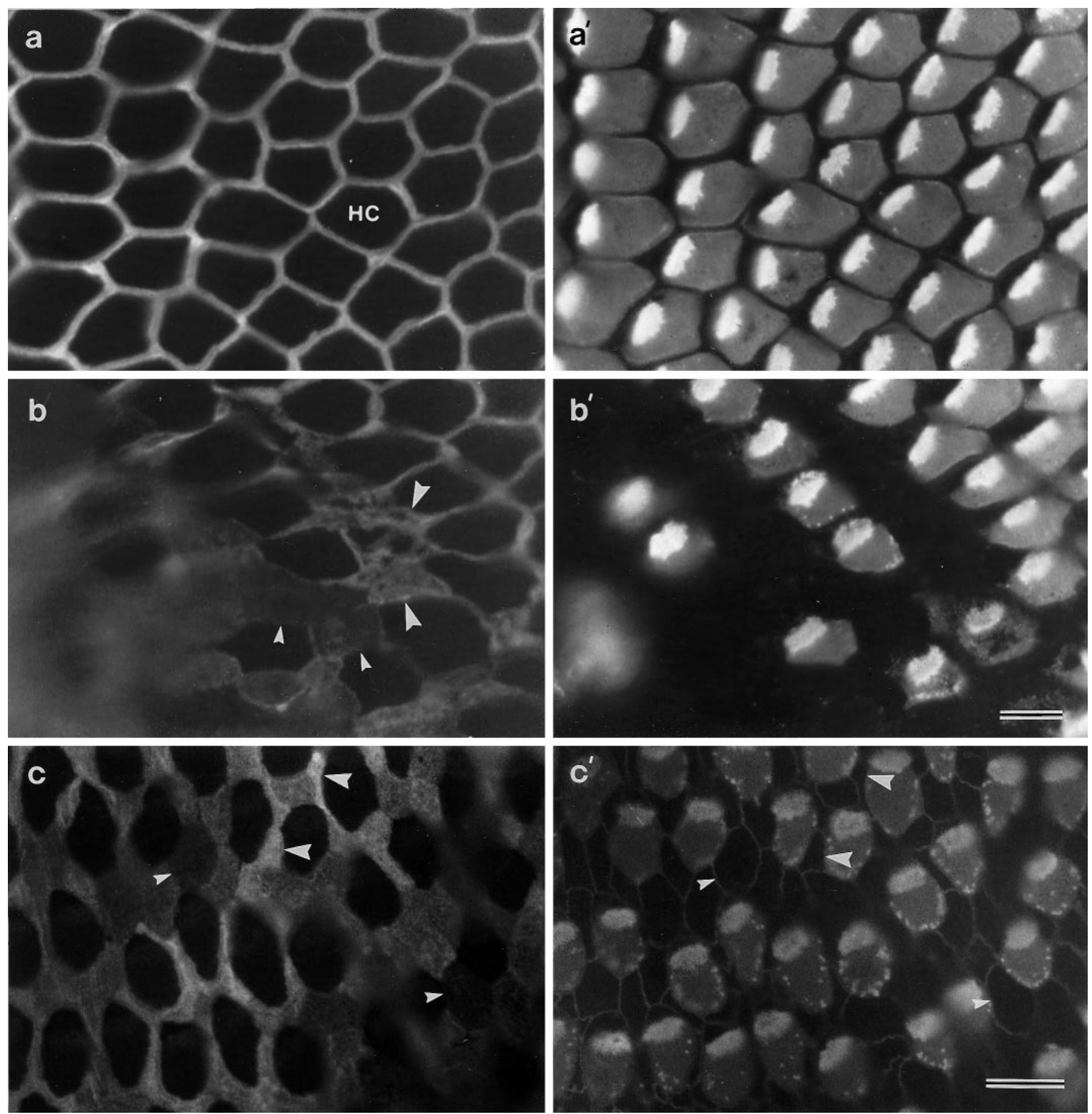

Figure 9. Whole-mount preparations from noise-damaged basilar papillae that have been double-labeled with mAb D37 $(a, b)$ and monoclonal anti-HCA $\left(a^{\prime}, b^{\prime}\right)$, or triple-labeled with mAb D37 $(c)$ and a mixture of monoclonal anti-HCA and cingulin $\left(c^{\prime}\right)$. Images in $a$ and $b$ are from a papilla exposed to octave band noise centered around $2.0 \mathrm{kHz}$ at $120 \mathrm{~dB}$ SPL for $14 \mathrm{hr}$; the image in $c$ is from a papilla exposed to a $900 \mathrm{~Hz}$ tone at $120 \mathrm{~dB}$ SPL for $12 \mathrm{hr} . a, a^{\prime}$, Area of the inferior basilar papilla just outside the noise-damaged region, showing narrow supporting-cell apical surfaces strongly labeled for the SCA $(a)$ and structurally normal, HCA-positive hair cells $\left(a^{\prime}\right) . b, b^{\prime}$, Edge of the noise-damaged region showing hair cells with varying degrees of damage. Note that supporting cells further into the damaged region express less SCA (small arrowheads) than supporting cells at the edge of the damaged region (large arrowheads). $c, c^{\prime}$, Region of a noise-damaged basilar papilla showing supporting-cell surfaces (c) that label strongly (large arrowheads) or very weakly for the SCA (small arrowheads). Note the speckled appearance of the HCA staining around the perimeter of the noise-damaged hair cells $\left(b^{\prime}, c^{\prime}\right)$. Scale bar (shown in $\left.b^{\prime}\right): a-b^{\prime}, 10 \mu \mathrm{m}$; (shown in $\left.c^{\prime}\right): c, c^{\prime}, 10 \mu \mathrm{m}$.

both human and rat, but differs from them in that the extracellular FN-III repeats show an unusual and much higher degree of internal similarity (Fig. 7). The FN-III repeats of the SCA share $54-94 \%$ identity, whereas the FN-III repeats of human DEP-1 have only $12-28 \%$ identity. The similarity of the FN-III repeats in the SCA indicates that they are derived from a recent exon duplication event or have been highly conserved to maintain function. 

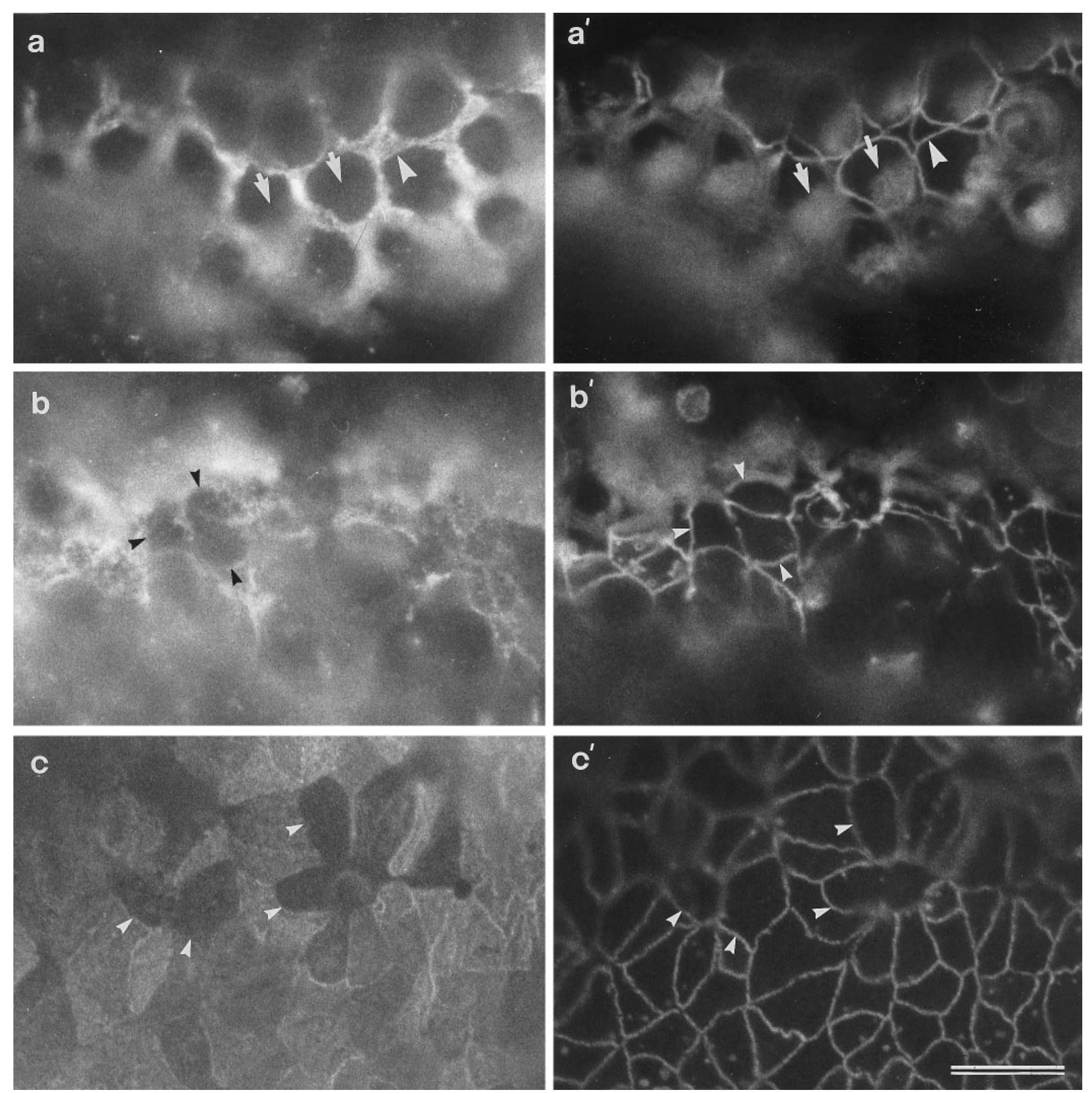

Figure 10. In vitro preparations of a control basilar papilla $\left(a, a^{\prime}\right)$ and basilar papillae that have been treated with either $1.0 \mathrm{~mm}\left(b, b^{\prime}\right)$ or $0.2 \mathrm{~mm}(c$, $\left.c^{\prime}\right)$ neomycin for $24 \mathrm{hr}$ and triple-labeled to visualize the SCA through one channel $(a-c)$, and both cingulin and the HCA simultaneously through the other channel $\left(a^{\prime}-c^{\prime}\right) . a, a^{\prime}$, In control papillae, strong staining for the SCA is seen on the supporting cells $(a)$ that surround the HCA-positive hair cells $\left(a^{\prime}\right)$. Arrowheads in $a$ and $a^{\prime}$ point to the same supporting cell; arrows point to the same hair cells. $b, b^{\prime}, c, c^{\prime}$, In neomycin-treated papillae, SCA-negative cells are seen that are in contact with each other (arrowheads). These cells are also HCA-negative and do not have the circular apical surfaces typical of hair cells $\left(a^{\prime}\right)$. Scale bar (shown in $c^{\prime}$ and applies to all panels): $10 \mu \mathrm{m}$.

The ligand for the SCA is not known, and thus far only a few RPTP ligands have been identified. RPTP $\mu$ interacts with itself, acting as a homophilic cell-cell adhesion molecule (BradyKalnay et al., 1993; Gebbink et al., 1993). RPTP $\beta / \zeta$ probably interacts with a complex composed of contactin, Nr CAM, and the contactin-associated protein caspr (Peles et al., 1995; Sakurai et al., 1997; Peles et al., 1997; for review, see Peles et al., 1998), and the laminin-nidogen complex can act as a ligand for the leukocyte common antigen-related receptor (O'Grady et al., 1998). The SCA cannot act as a homophilic cell-cell adhesion molecule on the apical surfaces of polarized epithelia, but the apical membranes of the supporting cells in the avian inner ear are in intimate contact with the extracellular matrices that overlie the sensory epithelia. Components of these matrices, such as chick $\alpha$ - and $\beta$-tectorin (Killick et al., 1995; Coutinho et al., 1999), are therefore candidate ligands. Although the tectorins are ex- 
pressed only in the inner ear and cannot be ligands in the other organs where the SCA is found, other extracellular molecules may interact with the SCA in these tissues. For example, the interphotoreceptor matrix, an extracellular matrix composed of glycoproteins and proteoglycans that surrounds the outer segments of the photoreceptors (Hageman and Johnson, 1991), contacts the Müller cell microvilli in the eye, and molecules that have regions of sequence similarity with the tectorins, such as the urinary protein uromodulin and the mucins (Killick et al., 1995; Legan et al., 1997), are associated with the brush borders in the kidney and intestine.

The proliferation of normal, nontransformed cell types requires the presence of exogenous growth factors, many of which operate via receptor tyrosine kinases, and it is the balance of protein tyrosyl phosphorylation that influences the growth state of a cell. Supporting cells proliferate when explants of the sensory epithelia of the avian inner ear are grown in serum-free medium (Warchol and Corwin, 1993), even if the epithelia are completely isolated from underlying stromal tissue, indicating that they can produce growth factors that act in an autocrine manner (Warchol, 1995). Growth factors that have been shown to influence supporting-cell proliferation include $\mathrm{TGF} \alpha$, epidermal growth factor (in combination with insulin), FGF2, and IGF1 (Yamashita and Oesterle, 1995; Oesterle et al., 1997; Zheng et al., 1997), and mRNAs for the receptors of all of these factors, including the insulin receptor, are present in the chick inner ear (Lee and Cotanche, 1996). Although it is not known which growth factors are operational in the ear in vivo, there is recent evidence that RPTPs can negatively regulate both insulin receptor (Kulas et al., 1995) and FGF receptor signaling pathways (Kokel et al., 1998). Interaction of the SCA with either of these two receptor tyrosine kinase pathways could control the level of protein phosphorylation in the supporting cells of the ear. Furthermore, a number of lines of evidence from in vitro studies indicate that some of the class III RPTPs with which the SCA shares sequence identity are involved in the control of cell growth and differentiation (Östman et al., 1994; Gaits et al., 1995; Borges et al., 1996; Keane et al., 1996). For example, human DEP-1 is upregulated when fibroblast cell lines reach density-dependent arrest of cell growth (Östman et al., 1994), and expression levels of mRNA for human DEP-1 and SAP increase when breast cancer cell lines are treated with sodium butyrate, a compound that induces cell differentiation and inhibits cell growth (Keane et al., 1996). Together these data prompt the hypothesis that the SCA controls either the proliferation or differentiation of supporting cells in the sensory epithelia of the inner ear.

If the SCA does play a role in controlling supporting-cell proliferation in the inner ear, levels of either SCA mRNA or protein may be expected to correlate with the proliferative state of the supporting cell, as described above for related RPTPs in dissociated cell culture. After hair-cell loss induced by either ototoxic drug treatment in vitro or noise damage in vivo, SCA expression levels clearly decrease on the apical surfaces of some, but not all, of the supporting cells in the basilar papilla. For the noise-damaged tissue, this decrease occurs before the time at which supporting cells first enter S-phase [ $18 \mathrm{hr}$ after the onset of noise exposure (Stone and Cotanche, 1994)] and may therefore be a primary rather than a secondary response to hair-cell injury. High levels of SCA expression may block cell proliferation but could also prevent cells from adopting the hair-cell phenotype. Whether these cells with decreased levels of SCA expression then go on to reenter the cell cycle and give rise to new hair and supporting cells, or differentiate directly into hair cells, remains to be determined and will be the focus of future studies.

\section{REFERENCES}

Adler HY, Raphael Y (1996) New hair cells arise from supporting cell conversion in the acoustically damaged chick inner ear. Neurosci Lett 205:17-20.

Altschul SF, Madden TL, Schaffer AA, Zhang J, Zheng Z, Miller W, Lipman DJ (1997) Gapped BLAST and PSI-BLAST: a new generation of protein database search programs. Nucleic Acids Res 25:3389-3402.

Bodden K, Bixby JL (1996) CRYP-2: a receptor-type tyrosine phosphatase selectively expressed by developing vertebrate neurons. J Neurobiol 31:309-324.

Borges LG, Seifert RA, Grant FJ, Hart CE, Disteche CM, Edelhoff S, Solca FF, Lieberman MA, Linder V, Fischer EH, Lok S, Bowen-Pope DF (1996) Cloning and characterization of rat density-enhanced phosphatase-1, a protein tyrosine phosphatase expressed by vascular cells. Circ Res 79:570-580.

Brady-Kalnay SM, Tonks NK (1995) Protein tyrosine phosphatases as adhesion receptors. Curr Biol 7:650-657.

Brady-Kalnay SM, Flint AJ, Tonks NK (1993) Homophilic binding of РТP $\mu$, a receptor protein tyrosine phosphatase, can mediate cell-cell aggregation. J Cell Biol 122:961-972.

Citi S, Sabanay H, Jakes R, Geiger B, Kendrick-Jones J (1988) Cingulin, a new peripheral component of tight junctions. Nature 333:272-276.

Corwin JT, Cotanche DA (1988) Regeneration of sensory hair cells after acoustic trauma. Science 240:1772-1774.

Cotanche DA, Messana EP, Ofsie MS (1995) Migration of hyaline cells into the chick basilar papilla during severe noise damage. Hear Res 91:148-159.

Coutinho P, Goodyear R, Legan PK, Richardson GP (1999) Chick $\alpha$-tectorin: molecular cloning and expression during embryogenesis. Hear Res 130:62-74.

Feinberg AP, Vogelstein B (1984) A technique for labelling DNA restriction endonuclease fragments to high specific activity. Ann Biochem 132:6-13.

Fekete DM, Muthukumar S, Karagogeos D (1998) Hair and supporting cells share a common progenitor in the avian inner ear. J Neurosci 18:7811-7821.

Fischer EH, Charbonneau H, Tonks NK (1991) Protein tyrosine phosphatases: a diverse family of intracellular and transmembrane enzymes. Science 253:401-406.

Gaits F, Li RY, Ragab A, Ragab-Thomas JMF, Chap H (1995) Increase in receptor-like protein tyrosine phosphatase activity and expression level in density-dependent growth of endothelial cells. Biochem J 311:97-103.

Gebbink MFBG, Zondag GCM, Wubbolts RW, Beijersbergen RL, van Etten I, Moolenaar WH (1993) Cell-cell adhesion mediated by a receptor-like tyrosine phosphatase. J Biol Chem 268:16101-16104.

Goodyear R, Richardson G (1999) The ankle link antigen: an epitope sensitive to calcium chelation associated with the hair-cell surface and the calycal processes of photoreceptors. J Neurosci 19:3761-3772.

Hageman GS, Johnson LV (1991) Structure, composition and function of the retinal interphotoreceptor matrix. In: Progress in retinal research (Osborne N, Chader GJ, eds), pp 207-250. Oxford: Pergammon.

Honda H, Inazawa J, Nishida J, Yazaki Y, Hirai H (1994) Molecular cloning, characterization, and chromosomal localization of a novel protein-tyrosine phosphatase, HPTP $\eta$. Blood 12:4186-4194.

Keane MM, Lowrey GA, Ettenberg SA, Dayton MA, Lipkowitz S (1996) The protein tyrosine phosphatase DEP-1 is induced during differentiation and inhibits growth arrest of breast cancer cells. Cancer Res 56:4236-4243.

Killick R, Legan PK, Malenczak C, Richardson GP (1995) Molecular cloning of chick $\beta$-tectorin, an extracellular matrix molecule of the inner ear. J Cell Biol 129:535-547.

Kohler G, Milstein C (1975) Continuous culture of fused cells secreting antibody of predefined specificity. Nature 256:495-497.

Kokel M, Borland CZ, DeLong L, Horvitz HR, Stern MJ (1998) clr-1 encodes a receptor tyrosine phosphatase that negatively regulates an FGF receptor signalling pathway in Caenorhabditis elegans. Genes Dev 12:1425-1437.

Krueger NX, Streuli M, Saito H (1990) Structural diversity and evolu- 
tion of human receptor-like protein tyrosine phosphatase. EMBO J 9:3241-3252.

Kulas DT, Zhang W-R, Goldstein BJ, Furlanetto RW, Mooney RA (1995) Insulin receptor signalling is augmented by antisense inhibition of the protein tyrosine phosphatase LAR. J Biol Chem 270:2435-2438.

Kuramochi S, Matsuda S, Matsuda Y, Saitoh T, Ohsugi M, Yamamoto T (1996) Molecular cloning and characterization of Byp, a murine receptor-type tyrosine phosphatase similar to human DEP-1. FEBS Lett 378:7-14.

Lee KH, Cotanche DA (1996) Potential role of bFGF and retinoic acid in the regeneration of chicken cochlear hair cells. Hear Res 94:1-13.

Legan PK, Rau A, Keen JN, Richardson GP (1997) The mouse tectorins: modular matrix molecules of the inner ear homologous to components of the sperm-egg adhesion system. J Biol Chem 272:8791-8801.

Matozaki T, Suzuki T, Uchida T, Inazawa J, Ariyama T, Matsuda K, Horita K, Noguchi H, Mizuno H, Sakamoto C, Kasuga M (1994) Molecular cloning of a human transmembrane-type protein tyrosine phosphatase and its expression in gastrointestinal cancers. J Biol Chem 269:2075-2081.

Navaratnam DS, Su HS, Scott S-P, Oberholtzer JC (1996) Proliferation in the auditory receptor epithelium mediated by cyclic AMP-dependent signalling pathway. Nat Med 2:1136-1139.

Neel BG, Tonks NK (1997) Protein tyrosine phosphatases in signal transduction. Curr Opin Cell Biol 9:193-204.

Oesterle EC, Rubel EW (1993) Postnatal production of supporting cells in the chick cochlea. Hear Res 66:213-224.

Oesterle EC, Tsue TT, Rubel EW (1997) Induction of cell proliferation in avian inner ear sensory epithelia by insulin-like growth factor-I and insulin. J Comp Neurol 380:262-274.

O'Grady P, Thai TC, Saito H (1998) The laminin-nidogen complex is a ligand for a specific splice isoform of the transmembrane protein tyrosine phosphatase LAR. J Cell Biol 141:1675-1684.

Östman A, Yang Q, Tonks NK (1994) Expression of DEP-1, a receptorlike protein-tyrosine-phosphatase, is enhanced with increasing cell density. Proc Natl Acad Sci USA 91:9680-9684.

Peles E, Nativ M, Campbell PL, Sakurai T, Martinez R, Lev DO, Clary J, Schilling G, Barnea G, Plowman GD, Grumet M, Schlessinger J (1995) The carbonic anhydrase domain of receptor tyrosine phosphatase $\beta$ is a functional ligand for the axonal cell recognition molecule contactin. Cell 82:251-260.

Peles E, Nativ M, Lustig M, Grumet M, Schilling J, Martinez R, Plowman GD, Schlessinger J (1997) Identification of a novel contactinassociated transmembrane receptor with multiple domains implicated in protein-protein interactions. EMBO J 16:978-988.

Peles E, Schlessinger J, Grumet M (1998) Multi-ligand interactions with receptor-like protein tyrosine phosphatase $\beta$ : implications for intercellular signalling. Trends Biochem Sci 23:121-124.

Raphael Y (1992) Evidence for supporting cell mitosis in response to acoustic trauma in the avian inner ear. J Neurocytol 21:663-671.
Raphael Y (1993) Reorganization of the chick basilar papilla following acoustic trauma. J Comp Neurol 330:521-532.

Richardson GP, Bartolami S, Russell IJ (1990) Identification of a 275 $\mathrm{kDa}$ protein associated with the apical surfaces of sensory hair cells in the avian inner ear. J Cell Biol 110:1055-1066.

Roberson DW, Kreig CS, Rubel EW (1996) Light microscopic evidence that direct transdifferentiation gives rise to new hair cells in regenerating avian auditory epithelium. Aud Neurosci 2:195-205.

Ryals BM, Rubel EW (1988) Hair cell regeneration after acoustic trauma in adult Cortinix quail. Science 240:1774-1776.

Sakurai T, Lustig M, Nativ M, Hemperly JJ, Schlessinger J, Peles E, Grumet M (1997) Induction of neurite outgrowth through contactin and $\mathrm{Nr}-\mathrm{CAM}$ by extracellular regions of glial receptor tyrosine phosphatase $\beta$. J Cell Biol 136:907-918.

Sanger F, Nicklen S, Coulson AR (1977) DNA sequencing with chain terminating inhibitors. Proc Natl Acad Sci USA 74:5463-5467.

Seimiya H, Sawabe T, Inazawa J, Tsuruo T (1995) Cloning, expression and chromosomal localization of a novel gene for protein tyrosine phosphatase (PTP-U2) induced by various differentiation agents. Oncogene 10:1731-1738.

Shin-Shay T, Tsoulfas P, Zinn K (1991) Three receptor-linked proteintyrosine phosphatases are selectively expressed on central nervous system axons in the Drosophila embryo. Cell 67:675-685.

Stoker A, Dutta R (1998) Protein tyrosine phosphatases and neural development. BioEssays 20:463-472.

Stone JS, Cotanche DA (1994) Identification of the timing of S-phase and the patterns of cell proliferation during hair cell regeneration in the chick cochlea. J Comp Neurol 341:50-67.

Thomas PE, Wharram BL, Goyal M, Wiggins JE, Holzman LB, Wiggins RC (1994) GLEPP1, a renal glomerular epithelial cell (podocyte) membrane protein-tyrosine phosphatase. J Biol Chem 269:19953-19962.

Yamashita H, Oesterle EC (1995) Induction of cell proliferation in mammalian inner-ear sensory epithelia by transforming growth factor alpha and epidermal growth factor. Proc Natl Acad Sci USA 92:3152-3155.

Yang X, Seow KT, Bahri SM, Oon SH, Chia W (1991) Two Drosophila receptor-like tyrosine phosphatase genes are expressed in a subset of developing axons and pioneer neurons in the embryonic CNS. Cell 67:661-673.

Warchol ME (1995) Supporting cells in isolated sensory epithelia of avian utricles proliferate in serum free culture. NeuroReport 6:981-984.

Warchol ME, Corwin JT (1993) Supporting cells in avian vestibular organs proliferate in serum-free culture. Hear Res 71:28-36.

Zheng JL, Helbig C, Gao W-Q (1997) Induction of cell proliferation by fibroblast and insulin-like growth factors in pure rat inner ear epithelial cell cultures. J Neurosci 17:216-226. 